\title{
Urgences
}

\section{La vie précise (extraits)}

Denuis Saint-Yves

Numéro 4, 2e trimestre 1982

URI : https://id.erudit.org/iderudit/025064ar

DOI : https://doi.org/10.7202/025064ar

Aller au sommaire du numéro

Éditeur(s)

Urgences

ISSN

0226-9554 (imprimé)

1927-3924 (numérique)

Découvrir la revue

Citer ce document

Saint-Yves, D. (1982). La vie précise (extraits). Urgences, (4), 71-80.

https://doi.org/10.7202/025064ar

Ce document est protégé par la loi sur le droit d'auteur. L'utilisation des services d'Érudit (y compris la reproduction) est assujettie à sa politique d'utilisation que vous pouvez consulter en ligne.

https://apropos.erudit.org/fr/usagers/politique-dutilisation/
Cet article est diffusé et préservé par Érudit.

Érudit est un consortium interuniversitaire sans but lucratif composé de l’Université de Montréal, l'Université Laval et l'Université du Québec à Montréal. Il a pour mission la promotion et la valorisation de la recherche. https://www.erudit.org/fr/ 


\section{DENUIS SAINT-YVES}

\section{La vie précise}

(Extraits) 
monsieur Denuis Saint-Yves

ou le vent qui bouge

j'avais 17 ans

un mal de chien à rattraper le temps perdu

des mots qui placés l'un devant l'autre

servaient tout juste

à me faire trébucher

monsieur Denuis Saint-Yves

ou le vent qui bouge

les drames juxtaposés avaient même valeur

(Danemark est une prison)

Québec est une prison

en parler

revenait à me faire regarder de trop près et bredouiller

j'étais sans preuve

discutable

la neige et le vent me reposaient de la neige et du vent 
j'ai pris en chasse L'espoir

il est tenace

et j'y vois des raisons chaque jour

de me lever

de chanter dans mon bain

de me débroussailler les cheveux

de me brosser les dents

disons-le de me faire beau

c'est une façon d'attraper L'espoir 
on a tant parlé du jour

qu'à la nuit le jour était encore là

il écoutait 
j'ai brossé le tableau

de mon visage pour qu'on y écrive

tout ce que je n'ai pas su dire 
nous avons décidé qu'il en serait ainsi

de l'être

des choses

des villes et des campagnes

de la joie qui forcément ne rejette pas la peine

du bonheur qui tend la main au malheur

du temps

de l'espace

de la vie qui prend la parole

à la place de la mort

pourtant tout reste à rassurer 
il entra dans sa chambre sur la pointe des pieds

il regarda autour de lui pour être bien sûr qu'il était seul

il se déshabilla lentement

sur la pointe des vêtements

il fit sa prière sur la pointe des lèvres

il éteignit la lumière

sur la pointe de ses paupières

et l'on n'entendit plus parler de lui

avant l'aube 
ai signé sur le registre un faux nom donné une fausse adresse pris la clé de la chambre et me suis évadé 
la cage était ouverte et des hommes y entraient croyant par là cerner l'espace 


\section{AM SORRY}

quand j'entends des personnes

parler de la glace à briser entre elles

je pense aux embâcles qui suivront 